\title{
A Hybrid Course for Probability and Statistics for Engineers: A Readiness Study at Shahid Beheshti University
}

\author{
doi:10.3991/ijet.v5i3.1211 \\ Amir Teimour Payandeh Najafabadi ${ }^{1}$ and Maryam Omidi Najafabadi ${ }^{2}$ \\ ${ }^{1}$ Shahid Beheshti University, G.C., Tehran, Iran \\ ${ }^{2}$ Science and research branch Islamic Azad University, Tehran, Iran
}

\begin{abstract}
Probability and Statistics for Engineers covers verities of subjects in the set theory, the combinatory analysis, probability, statistics, and (in some universities) the stochastic processes. Since, course receives only 3 credits it has to be thought 3 hours/week. This overloading content along with time limitation make course as a challenging and difficult one for students. Also, many instructors, including the first author, found the course very challenging to teach. Two popular on-site and e-learning training systems do not provide any appropriate solution. This article suggests a hybrid training system, which combines some elements of both training systems to reduce the disadvantages of both systems. Readiness of such hybrid course is measured by preparedness of students for online activities. The readiness study at Shahid Beheshti University shows that Internet skills, self-directed learning, learner attitude toward $e$ learning, e-mail skills, and software ability of students are factors which are significantly affect readiness of students.
\end{abstract}

Index Terms-Readiness, Hybrid course, Probability and Statistics for Engineers, E-learning.

\section{INTRODUCTION}

Probability and Statistics for Engineers is one of the challenging co urses fo $\mathrm{r}$ bot $\mathrm{h}$ i nstructors and st udents in engineering. Overloading of the course content, time limitation, and simultaneous offering the course with several difficult courses (such as fundam ental of physics, multivariate calculus, differential equations) transform an interesting course to a difficult on e. Some instructors suggest dropping some less important materials of the course, and teaching the rest with more care. But, the majority of them believe that the course contents have been chosen based upon students' needs i n other courses and their research. Therefore, it is reasona ble to em ploy a tr aining syste $\mathrm{m}$ which have n o time limitation and can be a dapted based upon learners' abilities.

An e-learning training syst em can provide an interactive, individualized, and repeatable environment to teach a subject. Un iversities are wit nessing $m$ any benefits o f elearning, su ch as co st sav ing, in creasing fle xibility, p roductivity, rapidly developing, deploy and update a course, providing an effectiv e train ing syste $m$, availability anytime and any where, providing broadly training opportunities, st aying com petitive, im proving m otivation and $\mathrm{m}$ orale, and im plementing st rategic i nitiatives more effectively (Bonk, 2002; So and Swatman, 2007; Minton, 2000 ). O $n$ the oth er han $d$, there are situations where a $n$ elearning training sy stem is not an appro priate one. $M$ any instructors believe that mathematics and statistics need the traditional face-to-face traini ng system and they cannot teach using an online traini ng syste m (Broadbent, 2001 and Chapnick, 2000).

To overc ome such bar riers and 1 imitations, several authors s uggest using a hy brid cou rse; see Garnham and Kaleta (2002) and Sands (2002), am ong others for more detail. Many universities have sought to develop their own hybrid learning courses as another option for students and instructors who prefer to replace some portion of traditional face-to-face meeting time with online instruction (Olapiriyakul \& Scher, 2006). In a hybrid training system, similar to the traditional training system, students participate in a cl assroom and 1 earn si gnificant $\mathrm{p}$ ortion of the course on-site. But, some complimentary activities such as advanced topi cs, assignm ents, quizzes, more exam ples, and etc are $\mathrm{m}$ oved to a $\mathrm{n}$ online part. The goal of hy brid courses is to join the best features of in-class teaching with the best features of online le arning to promote active independent learning and red uce class seat time (Garnham and Kaleta, 2002). Moreover, Arbaugh (2000) pointed out that hybrid courses $m$ ay be acco mpanied benefits of bot $h$ on-site and e-l earning techniques to reduce disadvantages of both techniques. To have a successful hybrid course an instructor must invest significant time and effort in redesigning a trad itional course. Since, online activities require special abilitie s, equipm ents, and etc. of learners. Garnham and Kaleta (2002) pointed out that readiness of a hybrid course measured by preparedness, mentally or physically, of learners in online activities.

Sands (2002) described how one $m$ ay integrate onl ine activities wi th classro om work to ob tain a su ccessful hybrid co urse. Based up on Sands' su ggestions, ou r ex perience, and several in-deep interview with some experts and instructors, we decide to design a hybrid course, which (i) the course contents teach in the On-site pa rt; (ii) Class materials companies with some new exa mples and $\mathrm{m}$ ore advanced materials as well as quizzes and assignments are moved to the On-line part.

This article re ports th e read iness of Sh ahid Beh eshti university (say SB U) students, who regi stered the cours e in 2009 winter semester. This article develops as the following. Section 2 reviews some relevant literature regarding readiness. Research's hypothesizes as well as statistical methods are given in Section 3. R esearch's design is given in Section 4 . While Section 5 repres ents results of the research. Finally, Secti on 6 p rovides a concl usion regarding our findings. 


\section{A Hybrid COURSe For Probability and Statistics For ENGINEERS: A READINESS Study at SHAHID BeHESHTI UNIVERSITY}

\section{LITERATURE REVIEW}

Webster's New Collegiate Dictionary defines readiness as bei ng prepa red, m entally or phy sically, for som e experience or act ions. B orotis and p oulymenakou (2004) defined e-learning readiness of an or ganization as pre paredness, m entally or phy sically, for s ome e-1 earning ex perience or actions.

Kaur and Abas (2004), Anderson (2002), Bean (2003), Chapnick (2000), Clark and Mayer (2003), and Gold et al. (2001) are aut hors, am ong others, who discussed the necessity of a re adiness study in an e-learning training system. They war ned th at with out a careful planning most likely an e-l earning system will be ended wi th cost overruns, unappealing $t$ raining $\mathrm{p}$ roducts, and failure. $\mathrm{M}$ oreover, they stated that (similar to any other major innovations) e-l earning st rategies $r$ equire co nsiderable up -front analysis, developm ent tim e, money, technological i nfrastructure, and leadership su pport to be successful. Therefore, managers must assess their companies' readiness for an e-l earning system, before im plementing $t$ his i nnovation. Several authors st udied fact ors $w$ hich $m$ ay affect readiness of learners. Table 1 summarizes some of their results.

\section{VARIABLES AND HYPOTHESIZES OF RESEARCH}

A two -section su rvey en titled, "e-Learning Readiness Survey" has been developed to assess e-learning readiness of st udents at SB U, wh o re gistered the course i n 2009 winter sem ester. The fi rst section consisted of $5 \mathrm{i}$ tems to gather dat a about dem ographic charact eristics, such as gender, schola stic success (which is measured by Gra d Point Average, GPA), major, computer usage, and Internet usage in the week who takes the survey. The second section included 41 item $\mathrm{s}$ to asse ss respon dents' self-report perceptions of their readines $s$ for an e-learning training system. Now observe that: (i) th e On-line part of the hybrid training system is a new part, which added to the traditional part. Therefore, it is reasonable to measure readiness of 1 earners for $t$ he hy brid $t$ raining syst em $t$ hrough their readiness for an online training syste m; (ii) $\mathrm{R}$ eadiness defi nes b ased upo $n$ m entally and phy sically preparedness of studen ts who will $p$ articipate the course. From these observations one can conc lude that, readiness of the hybrid training system (dependent variable) can be measured, only, by students' online preparedness, mentally and physically, using questions 1 to 9 . It is worth to mention that questions 1 to 5 assesses th e mental readiness while questions 6 to 9 assess the phy sical readiness of st udents in the survey.

DeVellis (2003) indicated that the first step in d eveloping an instrument is, clearly, d etermining what it is the researcher wants to measure. The variables, or factors, of this research identified afte $\mathrm{r} d$ etailed an alyses of th $\mathrm{e}$ available e-le arning readi ness assessm ent instrum ents, and au thors' personal ex perience. As a result, $12 \mathrm{~m}$ ajor factors that can be helped organizations to measure how ready they are for an e-learning training system are identified.

Based upon previous researches, partly given in Section 2 , a questionnaire devel oped t $\mathrm{o}$ m easure readi ness of a learner for the online course. Appendix A r epresents the questionnaire items as well as their sources. Now, the followings present the hypotheses of this research.

Hypothesis 1. Skills of users influence on learners' readiness for an online course.

Learners with $\mathrm{h}$ igh sk ills $\mathrm{h}$ ave more co nfident to accomplish e-lea rning activ ities an i mprove their satisfaction. Many studies explore influences of self-efficiency on users' recognition effects. Wang and Ne wlin (2002) from a research, on 122 students, concluded that students with higher skills are more inclined to adopt a network-base d learning sy stem and earned, si gnificantly, bet ter fi nal grades. Users' Sk ills wh ich considered in this stu dy are learners' ab ility to ev aluate their ab ility to use the so ftware, har dware, e- mail and Internet to perform an eLearning activity.

Hypothesis 2. Self-directed ability of learners influences learners' readiness for an online course.

In an online course, a learner goes through instructional material, delivered via the We $b$, at his/her own pace with no (m ore preci sely, wi th minimal) interaction fr om an instructor. Self-directed of 1 earners is a factor which can be used to measure whether or not a leaner can stand alone, whe never an instructor is not avai lable (Haney, 2001). Piskurich (2003) believes an ability to work alone, persistence in learning, and ability to devel op a pl an to complete a wo rk are su ch skills which may affect read iness of e-learners.

Hypothesis 3. Learners' attitude toward an online course influences on their readiness for the course.

Arbaugh (2002), Hong (2002), and Piccoli et al. (2001) are such authors, among others, who believe that learner's

TABLE I.

FACTORS AFFECTING LEARNERS’ READINESS

\begin{tabular}{|l|l|}
\hline \multicolumn{1}{|c|}{ Author } & \multicolumn{1}{c|}{ Factors } \\
\hline Schreurs et al (2009) & Resources (technological and human readiness), education, environment \\
\hline Koo (2008) & Individuals' language, discipline, experience in using e-mail, skill levels \\
\hline So and Swatman (2007) & $\begin{array}{l}\text { Students' preparedness, teachers' pre paredness, infrastructure, management Supp ort, school culture, } \\
\text { preference to meet face-to-face. }\end{array}$ \\
\hline Sun et al (2007) & Learner attitude toward computer, learner computer anxiety, technology quality, Internet quality. \\
\hline Liu (2005) & Trainee characteristics, training content, system design, working environment. \\
\hline Gunawardana (2005) & Instructional material, tutorial support, communication, collaboration \\
\hline Haney (2002) & $\begin{array}{l}\text { Employee co mpetency, develop ment needs, career paths and r ecords, cour se tr acking tec hnology, } \\
\text { infrastructure, supporting finance, vendor offerings. }\end{array}$ \\
\hline Chapnick (2000) & $\begin{array}{l}\text { Psychological, sociological, hu man-resource, financial, technological skill (aptitude), e quipment, } \\
\text { content readiness. }\end{array}$ \\
\hline Gastaldo et al (2005) & User characteristics, accessibility to computer equipment, knowledge, attitudes toward ICT \\
\hline
\end{tabular}


attitude, towards e-learning, are an im portant factor in elearning readi ness. Learner' $s$ at titude can be defi ned as learner's impression to participate in an e-le arning activity. In structors $\mathrm{p}$ ost th eir $\mathrm{m}$ aterials on the platform and learners part icipate through c omputer net works. A m ore positive atti tude to ward e-l earning, for ex ample, wh en students are not afraid of the complexity of using com puters, will result in more satisfaction and effectiveness of learners in a $\mathrm{n}$ e-learning environment (Piccoli et al. 2001). Fu rthermore, p ositive att itudes to ward e-learn ing increase the $c$ hances of succ ess of an e-learning syste $\mathrm{m}$, while negative attitudes reduce it. Therefore, this research considers learners' attitu de to wards co mputers as an important factor in e-learning readiness.

Hypothesis 4. Learners' computer anxiety influences on their readiness for an online course.

Piccoli et al. (2001) bel ieve computer anxi ety, significantly, affects an e-learning environment. Computers are communication t ools in e-l earning environments. Therefore, any fear in com puter usage would certainly hamper learning (Piccoli et al., 2001) . C omputer anxiety is an emotional fear wh ich co mes u p so me potential n egative outcomes, such as dam aging to equi pments or 1 ooking foolish (Barbeite and Weiss, 2004). The higher computer anxiety causes the lower level of e-learning readiness. The definition of computer anxiety in this research is the level of learners' anxiety, when they apply computers.

Hypothesis 5. Equipments influence on learners' readiness for an online course.

Other fact ors contributing to an increase in e-learning readiness are the $i$ nfrastructure of $t$ echnology and t echnical support of an e-l earning sy stem. It is im portant to bring into account the reliability and quality of the system, because they play important ro les in e-learning readiness. To build an acceptable e-learning environment, one has to maintain and up-t o-date t echnology and material represented by the environment (Folorunso et al., 2006; Poon et al., 2004; Selim, 2005).

Hypothesis 6. Scholastic success of learners, influence on learners' readiness for an online course.

Carmel and Gold (2007) pointed out those learners who reported hi gher readi ness t ended to be $\mathrm{m}$ ore successful, scholastically.

Hypothesis 7. Gender of learners influences on learners' readiness for an online course.

Summer (199 0) an d M cMahon an d Ga rdner ( 1995) found out that male students experience less anxiety about ICT than fem ale st udents. M oreover, Ol iver (1 993) an d Van B raak (2 001) di scovered that fem ale students have lower confidence or knowledge ability than males regarding com puter usage. However, many other authors (s uch as K oohang, 1989; K ay, 1 989; H unt an d Bohlin, 1993; Marshall and Bannon, 1986; Woodrow, 1991 among others) are agree with the claim that "there are no significant different between attitude of male and female students regarding ICT usage".

Hypothesis 8. Major of learners influences on their readiness for an online course.

Summers and Easdown (1996) mentioned that student's major and specialization are such factors which influence on e-learning's readiness.

\section{RESEARCH DESIGN}

A series o $\mathrm{f}$ in -depth in terviews, with $\mathrm{v}$ arious ex perienced e-learning and instructor s of the course, have been conducted to examine the validity of our res earch model. After that, questionnaire items developed based upon previous literatu re an $d$ co mments $g$ athered fro $m$ the in terviews. Questionnaires were revised with help from experts (including academic s and practitioners ) wi th significant experience in e-learning and Probability and Statistics. A 5-point Likert scale ranging from 1, as strongly disagrees, to 5 , as strongly agrees, is used for the measurement.

A pret est, to measure val idity and rel iability of st udy, was con ducted wi th 3 i nstructors and 2 e-l earning's e xperts. Fol lowed by pret est to veri fy rel iability of questionnaire, a pi lot t est has been con ducted u sing 20 ra ndomly chosen students from the target population. Questions reg arding sk ills of $\mathrm{u}$ sers, on line au dio/video, selfdirected leanin $g$, learner att itude t oward l earning, l eaner computer anxiety, equip ments, and e-learning readiness can be su mmarized into 7 single factors $F_{1}, \ldots, F_{7}$. The Cronbach's alpha from those factors are $80.2 \%, 75.34 \%$, $95.01 \%, 89.32 \%, 73.02 \%, 89.54 \%$, an d $78.93 \%$ r espectively, which indicate an acceptable reliability of the questionnaire.

The research population included all undergraduate students in computer and electronic majors, who registered in the Probability and Statistics course in 2009 winter semester at SB U (wi th pop ulation si ze $\mathrm{N}=130$ ). Aft er a pi lot test, a census st udy was c onducted by distributing the questionnaire among all st udents. Thi s sur vey generat ed 109 useable responses from students resulting in a response rate of $83.8 \%$, which is indicated that the respondents found the topic interesting and relevant.

This research used two sta tistical packages, Minitab 13, SPSS 16 , to analyze the data. Data was analyzed using the following two techniques.

\section{A. Ordinal Logistic Regression}

The bi nary 1 ogistic regression i s a wel l-known $\mathrm{t}$ echnique to set up a general ized linear model for the bi nary dependent vari able. $B$ ut for multiple ordi nal depende nt variables, $t$ he binary 1 ogistic regressi on d oes not work properly. St atisticians devel oped an or dinal 1 ogistic regression to ha ndle multiple ordinal de pendent vari ables. Minitab 13 is a statistical software package that can fit an ordinal logistic regression to data. The out put of the software i ncludes: ( 1) Response and Factor Information, which di splays the nu mber of obse rvations and $t$ he response and factor cat egories; (2) Logistic Regression Table, which shows the estimated coefficients, p-values (related to a tes $t$ that the corresponding coefficient is zero), and odds ratio (which shows effect of each variables on the m odel); (3) Goodness-of-Fit Tests, w hich di splays both Pearson goodness-of-fit test of the model to data. The steps in model building for an ordinal logistic model are similar to those for the bi nary logistic regressi on model. Unfortunately, the fu $\mathrm{ll}$ array o f m odeling to ols is no $\mathrm{t}$ available in the softwa re packages. So, one has to choose a final and appropriate $m$ odel by en tering variables with significant coefficients ( $p$-value $<0.05)$ and ordering effect of vari ables fr om their Odds ratio (negative coefficient along smallest odds ratio indicate more impact of the variable on $\mathrm{t}$ he de pendent vari able, M cCullagh and Nel der, 1992). Finally, appropriative of model is evaluated by (i) a 
TABLE II.

DEMOGRAPHIC PROFILE AND DESCRIPTIVE STATISTICS OF STUDENTS

\begin{tabular}{|l|l|l|}
\hline Sex & Female (42.20\%) & Male (57.80\%) \\
\hline Province & Tehran (77.78\%) & Other $(22.22)$ \\
\hline Major & Computer (33.03\%) & Electronic (66.97\%) \\
\hline Computer usage (daily)/hour & Mean=3.058 S.D=1.811 & \\
\hline Internet usage (daily)/hour & Mean=2.159 S.D=1.519 & \\
\hline
\end{tabular}

TABLE III.

PERSONAL AND UNIVERSITY FACILITIES

\begin{tabular}{|l|c|c|}
\hline Having Laptop & Yes (55.05) & No (44.95) \\
\hline Having an appropriate personal computer & Yes (94.50) & No (5.50) \\
\hline Internet connection at home* & Dial-up (60.55) & ADSL (9.17) \\
\hline Internet connection at university* & Wireless (62.38) & Wire (27.72) \\
\hline Having a cell-phone & Yes (100\%) & No (0\%) \\
\hline Having an appropriate memory stick & Yes (88.07) & No (11.93) \\
\hline *
\end{tabular}

G test wh ose its $n$ ull h ypothesis states a 11 the co efficients associa ted with pre dictors equal zero vers us at least one coefficient is not ze ro (we prefer to reject its null hy pothesis, i.e., p-value $<0.05$ ) and (ii) Goodnessof-Fit Tests, (we prefe $r$ to a ccept its null hypothesis, i.e., p-value $>0.1$ ), more can be foun $\mathrm{d}$ in Hosmer and Lemeshow (2000) an d McCullagh and Nel der (1992), among others.

\section{B. Contingency table}

A co ntingency $t$ able (or cr oss $t$ abulation) describes the di stribution o $\mathrm{ft}$ wo or more vari ables sim ultaneously. Each cell shows the number of respondents, who gave a specific combination of responses. Since contingency table is easy to understand, can be used with any kind of data, (the contingency tables treat no minal, ordinal, interval, and ratio scales as a nom inal scale), provides g reater i nsight than si ngle st atistics, and ca $n$ be used as a tool to measure association among variables is one of most popular techniques in statistics. In a twoways contingency table, there are several statistical tests can be used to test hypothesis:

\section{$H_{o}$ : Row's Variable influences on variable in column, vs. $H_{1}$ : Rejection of $H_{o}$.}

Which the chi -square t est is the most pop ular one. The small enoug $\mathrm{h} p$-value of the test (l ess than 0.05) indicates that there is no evidence for association between these variables.

\section{RESUlTS AND DisCUSSION}

Demographic profile and descri ptive statistics of target population are summarized in Table 2 .

Table 3 summarizes personal facilities and attitude of students about university facilities.

\section{A. Ordinal Logistic Regression}

As mentioned the above, sev eral 5-point Likert scale variables have been used to measure readiness of a learner (see Appendix A). To summarize such variables into a single one, say the dependent variable, one has to use $\mathrm{t}$ he $\mathrm{m}$ edian, $\mathrm{w}$ hich i s an appropriate central tendency for Like rt scale variables, see Agresti, 2003 a nd Johnson at al, 1999, among others. Therefore, readiness of each learner has 9 levels, b ecause median of those 5point Li kert scal e vari ables generat es 1, 1. 5, 2, 2. 5, 3, $3.5,4,4.5$, and 5 .

To di scover a ffect of $i$ ndependent vari ables the dependent vari able an ordi nal logistic regressi on can be employed. The fol lowing table represents coefficients, $\mathrm{p}$-values and odds ratios of such ordinal logistic regression.

Results of Table 4 (bel ow) can be summarized as the following:

1. There is significant evidence to conclude that skills of u sers (e-m ail sk ills), sk ills of u sers (software ability), sk ills o f u sers (In ternet sk ills), selfdirected learn ing, and learn er attitu de to ward elearning are s uch variables whose a ffect learning readiness, the dependent variable (their p-values is smaller than 0.05).

2. Small odds ratio indicates that im pact of si gnificant fact ors can be or dered a s (1) sk ills of u sers (Internet sk ills), ( 2) self-di rected learning, ( 3 ) learner attitude toward e-learning, (4) skills of users (e-mail skills), and (5) skills of users (software ability).

3. $P$-value $=0.00$ fo $r$ test th at "all coefficie nts are zero" al ong with $t$ he $p$-va lue $=0.899$ fo $r$ " $t$ he Goodness-of-Fit Test s" i ndicate that the ordi nal logistic regression is an appropriate model to analyze the data.

4. The ordi nal 1 ogistic regressi on gi ves $8 \mathrm{p}$ arallel equations $(i=1,2, \ldots, 8)$

$$
\gamma_{i}=\frac{\exp \left\{\alpha_{i}-3.212 X_{1}-3.321 X_{2}-0.232 X_{3}-1.232 X_{4}-2.330 X_{5}\right\}}{1+\exp \left\{\alpha_{i}-3.212 X_{1}-3.321 X_{2}-0.232 X_{3}-1.232 X_{4}-2.330 X_{5}\right\}},
$$

where $\gamma_{i}$ is the cu mulative $\mathrm{p}$ robability of $i^{\text {th }}$ level of the dependent variable and $\alpha_{1}, \alpha_{2}, \ldots, \alpha_{8}$ are constant values, which given in Table 5. 
TABLE IV.

ORDINAL LOGISTIC REGRESSION

\begin{tabular}{|c|c|c|c|c|}
\hline & \multicolumn{4}{|c|}{ Dependent variable, i.e., efficiency of the model. } \\
\hline & Coefficient & P-value & Odds ratio & $\begin{array}{l}\text { Rank } \\
\text { order }\end{array}$ \\
\hline$\alpha_{1}$ & 0.8420 & 042 & - & 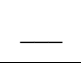 \\
\hline$\alpha_{2}$ & 1.8050 & 000 & - & $\longrightarrow$ \\
\hline$\alpha_{3}$ & 0.3450 & 001 & - & 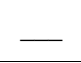 \\
\hline$\alpha_{4}$ & 0.3520 & 000 & $\longrightarrow$ & 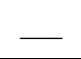 \\
\hline$\alpha_{5}$ & 0.4520 & 000 & - & 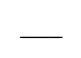 \\
\hline$\alpha_{6}$ & 2.4520 & 005 & - & - \\
\hline$\alpha_{7}$ & 3.4520 & 021 & - & - \\
\hline$\alpha_{8}$ & 4.3200 & 000 & - & - \\
\hline Skills of users (e-mail skills), say $X_{5}$ & -2.3300 & 040 & 1.3335 & 5 \\
\hline Skills of users (hardware ability) & -0.321 & 0.091 & 0.211 & - \\
\hline Skills of users (software ability), say $X_{4}$ & -1.2320 & 000 & 1.321 & 4 \\
\hline Skills of users (Internet skills), say $X_{1}$ & -3.2120 & 003 & 0.210 & 1 \\
\hline Self-directed learning, say $X_{2}$ & -3.3210 & 000 & 0.321 & 2 \\
\hline Learner attitude toward e-learning, say $X_{3}$ & -0.2320 & 001 & 0.983 & 3 \\
\hline Learner computer anxiety & -0.302 & 0.230 & 0.442 & - \\
\hline Equipments (hardware) & -2.123 & 0.410 & 0.662 & - \\
\hline Equipments (software) & -0.091 & 0.621 & 0.421 & - \\
\hline Equipments (Internet) & -0.001 & 0.832 & 0.321 & - \\
\hline Online audio video & -0.129 & 0.785 & 3.211 & - \\
\hline p-value of $g$ & -of-fit test $=0$ & & & \\
\hline p-value of test that & fficients are & $=0.002$ & & \\
\hline
\end{tabular}

TABLE V.

HYPOTHESIS'S RESULT

\begin{tabular}{|l|l|l|l|l|}
\hline $\begin{array}{c}\text { Hypothesis } \\
\text { number }\end{array}$ & $\begin{array}{c}\text { Chi-square } \\
\text { statistic }\end{array}$ & $\begin{array}{c}\text { Degree of free- } \\
\text { dom }\end{array}$ & p-value & \multicolumn{1}{|c|}{$\begin{array}{c}\text { Result on } H_{o} \text { at significant level } \\
\alpha=0.05\end{array}$} \\
\hline 113.114 & & 8 & 0.892 & Accepted \\
\hline 24.893 & & 8 & 0.231 & Accepted \\
\hline 39.817 & & 16 & 0.124 & Accepted \\
\hline 43. & 942 & 16 & 0.001 & Rejected \\
\hline 50. & 464 & 8 & 0.000 & Rejected \\
\hline 63.515 & & 8 & 0.102 & Accepted \\
\hline 71. & 596 & 8 & 0.009 & Rejected \\
\hline 817.435 & & 16 & 0.642 & Accepted \\
\hline
\end{tabular}

\section{B. Hypothesis tests:}

As pointed out the above, readiness of each learners is a 91 evel variable to test the given hypothesizes, one has to categori ze the second variable in each hypothesizes i nto so me l evels. Popu lation can be categorized into some groups regarding skills (low and high), selfdirected abi lity (l ow and hi gh), l earners' attitude to- ward the online course (negative, neutral, and positive), learners' computer anxiety (negative, neutral, and positive), IC T's equi pments (en ough and 1 ack), gen der (male and female), major (computer sciences and Electronic), and sc holastic succes s, according to their GPA (week, GPA $<12$, average, $12 \leq \mathrm{GPA}<17$, and str ong, $\mathrm{GPA} \geq 17)$. The contingency analysis has been con 


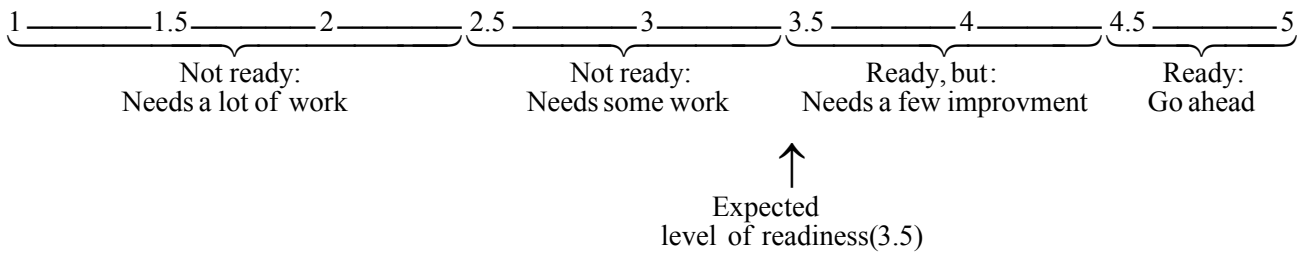

Figure 1. Discriminative index to identify level of readiness of each individual

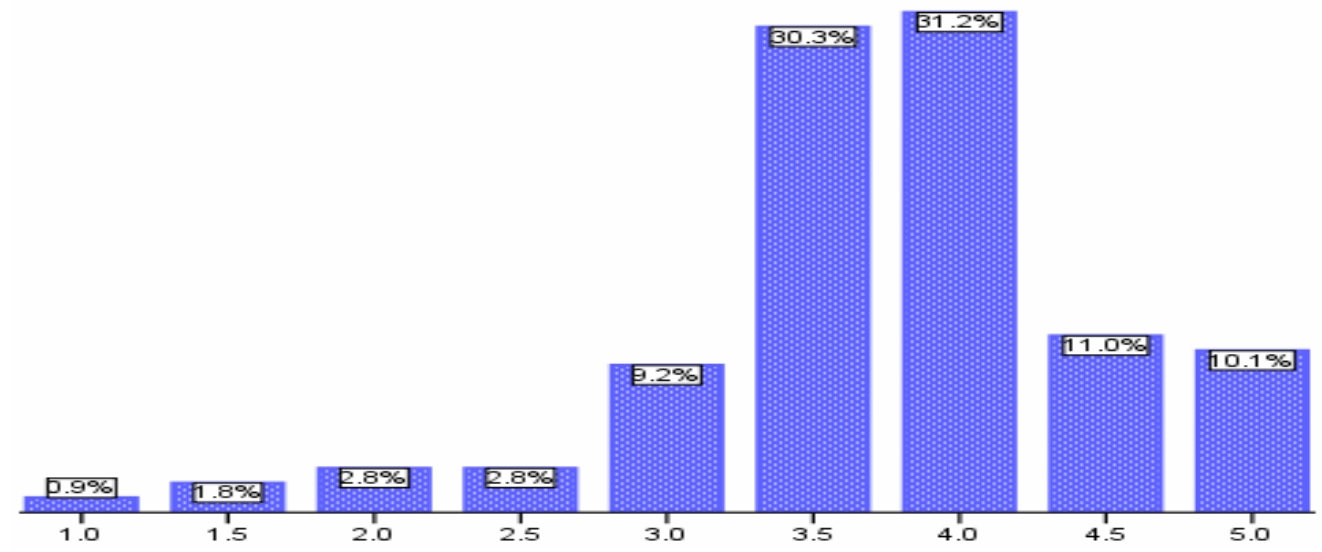

Figure 2. Distribution of the target population regarding level of readiness.

ducted t o see $t$ est the gi ven 8 hy pothesizes. R esults summarized in Table 4.

From Table 4, one can observe that:

1. Computer anxi ety, equi pment, and gen der of students do not affect their readiness reading the online training system.

2. Skills, self-d irected ab ility, attitude to ward th e online $t$ raining sy stem, schol astic, and $m$ ajor of students affect their readin ess reading the training system.

In order to $\mathrm{h}$ elp managers of u niversities, we in troduce a d iscriminative in dex to id entify lev el of read iness of each individual. Figure 2 duplicates such index.

The bar chart above d uplicates level of readi ness of the $t$ arget pop ulation, regar ding the ab ove discriminative index.

Using the discriminative index, provided by Figure 2, one can observe that, more than $80 \%$ of the target population is ready for $\mathrm{t}$ he onl ine course and co nsequently for the hy brid course. B ut, they need so me im provements, which vary from an individual to another one.

\section{CONCLUSION AND SUGGESTION}

This st udy made theoretical and p ractical cont ributions to the literature of the hybrid course readiness and more specifically on students' perceptions of the hybrid course im plementation at SBU. The em pirical results showed that the most of factors that were extracted from the $d$ ata were $g$ enuinely sig nificant in $p$ redicting th $\mathrm{e}$ criterion vari able. Our fi ndings co uld hav e pract ical importance for any uni versity as whose $p$ lanning to implement su ch h ybrid cou rse. Un iversities, in th eir rush to im plement the hybrid courses often place too much e mphasis on the equ ipment and to o little on the human part. So, this research comes up with authorizes must take a hard look at skills of users (Internet skills), self-directed learn ing, learner attitu de $\mathrm{t}$ oward elearning, skills of users (e-mail skills), and skills of users (soft ware abi lity) even $t$ hought other $n$ onsignificant, sta tistically, fact ors sh ould b e tak en in to account to have efficient a nd successful hybrid training system.

This study was the first part of a 1 ong term project, which desi gnation and im plementation of $t$ he hy brid course a nd st udy sat isfaction and follow-up st udy are the last part of such project. Already, the second part of the project has been started. Th e On-lin e p art of th e hybrid course available at: http://faculties.sbu.ac.ir/ $\sim$ payandeh/efront/www/index.php?logout=true, $w$ here students in summer semester, in 2009 , used it to write quizzes, download and upload assignments, and review the course materials.

To design the website, we us e an ope n source $\mathrm{W}$ eb designer nam ed Efront. Efron t p rovides abili ty to the Web administrator to orient e-learn ers' activities by (i) defining some rules for e-learners; (ii) providing a complete database about activities of e-learners on the webpage; ( iii) ability to ass ign, randomly, a quizzes to learners. Oth er Efro nt's ab ilities may be fo und in Zaharia (20 07) and i ts offi cial websi te avai lable at http://www.epignosis.com.gr/.

\section{REFERENCES}

[1] Anderson, T. (2002). Is e-learning right for your organization? Learning Cir cuits: AST D's Online M agazine All About E Learning, available at: http://www.learningcircuits.org/ 2002/jan2002/anderson.html.

[2] Agresti, A. (2003). Categor ical data analysis. John Wiley and Sons.

[3] Arbaugh, J. B. (2000). Vir tual classr oom char acteristics and student satisfaction with Intern et-based MBA courses. Journal of $\mathrm{M}$ anagement $\mathrm{E}$ ducation, 24( 1), 32-54. doi:10.1177/ 105256290002400104

[4] Barbeite, F. G., and W eiss, E . M. ( 2004). Co mputer selfefficacy and anxiety scales $\mathrm{f}$ or an Internet sa mple: testing 
measurement equivalence of existin g measures and development of new scales. Computers in Human Behavior, 20, 1-15. doi:10.1016/S0747-5632(03)00049-9

[5] Bean, M. (2003). Are you ready for e-learning? Asses sing elearning readiness. MediaPro Newsletter: Tips and tricks of the trade, avail able a t: http://www.mediapro.com $/ \mathrm{html} / \mathrm{resources} /$ news1-vol5-01.htm.

[6] Bonk, C. J. (2002). Online tr aining in an onli ne world, available at: www.CourseShare.com.

[7] Borotis, S. and Poulymenakou, A. (2004). E-learning readiness components: key issue to consider b efore adopting e- learning interventions. Available at: http://www.eltrun.gr/papers/ elreadiness elearn2004.pdf

[8] Broadbent, B. (2001). Tips to help decide if y our organization is ready $\mathrm{f}$ or e- learning, Available at: http://icde.net/en/ arshive/articles/012.htm.

[9] Carmel, A. and Gold, S. (2007). The effects of cour se delivery modality on student and satisfaction and retentions and GPA in on-site vs. Hy brid cour se. T urkish online J ournal of distance education. 8(2) $11-25$.

[10] Chapnick, S. (2000). Are y ou ready for e-learning? Available at: http://www.astd.org/ASTD/resources/dyor/article archives. $\underline{\mathrm{htm}}$

[11] Clark, R. C., and Mayer, R. E. (2003). e-Learning and the science of instr uction: Proven guidelines for custom ers and designers of multimedia learning. (2nd ed.) Wiley and Sons.

[12] DeVellis, R. F. (2003). Scale development: Theory and application (2nd ed.), Publisher: CA: Sage.

[13] Efront of ficial website, available at: http://www.epignosis. com.gr/.

[14] Folorunso, O., Og unseye, O. S., and Shar ma, S. K. (2006). An exploratory study of the critical factors affecting the acceptability of e-learning in Nigerian universities. Information Management and C omputer Secur ity, 14( 5), 496-505. doi:10.1108/09685220610717781

[15] Garnham, C . and Kaleta. R. (2002). I ntroduction to Hy brid Courses. University of $\mathrm{W}$ isconsin-Milwaukee, avail able at: http://www.uwsa.edu/ttt/articles/garnham.htm

[16] Gastaldo, I,. Alnerich,G. , Diaz,I . Bo, R., and Suarez,J.M.(2005). Analysis of ICT training needs according to gender in primary and secon dary school teachers. Available at: www.formatex.org/micte2005/164.pdf.

[17] Gattiker, U. E., and Hlavka, A. (1992). Computer attitudes and learning per formance: I ssues for management education and training. Jour nal of Or ganizational Behavior, 13(1), 89-101. doi:10.1002/job.4030130109

[18] Gold, A., Malhotra, A., and Se gars, A. H. (2001) Knowledge management: An organizational capabilities perspective. Journal of Management Information Systems, 18 (1), 185-214.

[19] Graeve,E.A.(1987). Patterns of self-directed professional learning of $r$ egistered nur ses. Doctor al Dissertation Univer sity of Minnesota.

[20] Guglielmino, P. J. and Guglielm ino, L .M. ( 2002). Are you learners ready for e-learning? AMA handbook of online learning. New York American Management Association.

[21] Gunawardana, K.D. (2005). An em pirical study of potential challenges and $\mathrm{b}$ enefits o f im plementing e- learning in $\mathrm{Sr}$ iLanka. Proceedings of the seco nd international conf erence on e-learning for knowledge-based society. Bangkok-Thailand.

[22] Haney, D. ( 2002). Assessing or ganizational $r$ eadiness for elearning: 70 questions to ask. Performance improvement, available at: www.ispi.org.

[23] Hong, K.S. (2002). Relationship between students a nd instructional var iables with satisfaction an d lear ning fr om a W ebbased cour se. I nternet and hi gher education, 5, 267-281. doi:10.1016/S1096-7516(02)00105-7

[24] Hosmer, D. W. and Lemshow, S. (2000). Applied logi stic regression. 2nd ed. John W illey and S ons, Inc. doi: $10.1002 / 0471722146$

[25] Hunt, N. P . and Bohlin, R.M. (1993). Tea cher educa tion students' attitudes toward using co mputers, Journal of Research on Computing in Education, 25, 487-497.
[26] Joo, Y. J., Bong, M., and Choi, H. J. (2000). Se lf-efficacy for self-regulated learning, acade mic s elf-efficacy, and Internet self-efficacy in Web based instruction. Educational Technology Research and Development, 48( 2), 5-17. doi:10.1007 BF02313398

[27] Johnson, V. E., Albert, J. H., and Albert, J (1999). Ordinal data modeling. Springer.

[28] Kay, R. H. (1989). G ender diffe rences in co mputer attitudes, literacy, locus of control and co mmitment, Journal of Research on Computing in Education, 21, 307-316.

[29] Kaur, K. and Abas, Z . (2004). An assess ment of e- learning readiness at the open university Mal aysia. Proceeding of international con ference on co mputers in education. (ICCE2004), Melbourne, Australia.

[30] Kim, K. J. ( 2005). Adult lear ners' m otivation in self dir ected learning e-learning. Ph.D. Dissertation. Indiana University.

[31] Koo, A.C. (2008). Fact ors affecting teachers' perc eived readiness for online collaborative learning: a case study in Malaysia. Educational technology soci ety. Available at: http://findarticles.com

[32] Koohang, A. A. (1989). A study of attitude towards computers: anxiety, confidence, liking and perception of use fulness, Journal of Research on Computing in Education, 22, 137-150.

[33] Liu, H. (2005). Discussion ab out fa ctors affecting e- learning training transfer. Master Thesis, human resources management, available at: http://etd.Lib.nsysu.edu.tw.

[34] Marshall, J . C. an d Bannon, S. H. (1986). Co mputer attitudes and co mputer knowledge of st udents and ed ucators. Association for Education Data Systems Journal. 18, 270-286.

[35] McCullagh, P. and Nelder, J. A. (1992). Gener alized linear model. Chapman and Hall Inc.

[36] McMahon, J. and Gardner, J. (1995). Facilitating and inhibiting factors in student computer usage. In o'Hagen, C.O. (Ed.). Empowering teachers and learners thro ugh technology. Birmingham: Staff and Educational De velopment Association. ISB N: 0946815143.

[37] Minton, M . C. (2000) . I s y our or ganization r eady for elearning? Seven key questions you need to answer.

[38] Communication Project Magazin e, 3 (1), avail able at: http://www.comproj.com/Minton.htm

[39] Nakhoda, M., Hori,A. Ka ramdoost, N.(2006). Individual factors on applicatio $\mathrm{n}$ of I CT by $\mathrm{T}$ ehran Univer sity Librarian. Journal of psychology and educational sciences. 35(1), 28-35.

[40] Olapiriyakul, K. \& Scher, J. M. (2006). A guide to establishing hybrid learning courses: Employing information technology to create a new learning experience, and a case study. Inter net and Higher E ducation, 9, 2 87-301. doi:10.1016/j.iheduc. 2006.08.001

[41] Oliver, R. (1993). A comparison of students' information technology skills in 1985 and 1991, Br itish Journal of Educational Technology, 24, 52-62. doi:10.1111/j.1467-8535.1993. tb00641.x

[42] Poon, W.C., L ow, L.T., and Yong, G. F. ( 2004). A s tudy of Web-based learning (WBL) environment in Malaysia. The International Jour nal of E ducational M anagement, 18(6), 374385. doi:10.1108/09513540410554031

[43] Piccoli, G., Ahmad, R., and Ives, B. (2001). Web-based virtual learning environments: a research framework and a preliminary assessment of effectiveness in basi c IT skill training. MIS Quarterly, 25(4), 401-426. doi:10.2307/3250989

[44] Sands, P. (2002). Inside Outside, Upside Downside: Strategies for Connecting online and Face-to-

[45] Face Instruction i n Hybrid Cour ses. University of Wi sconsinMilwaukee, avai lable at: http:/www.uwsa.edu/ttt/articles/ sands2.htm

[46] Schreurs, J. , Ehler, U., M oreau, R. ( 2009). M easuring elearning readiness. Available at: http://uhdspace.uhasselt.be/ dspace/bitstream/1942/8742/1/ICL08.pdf.

[47] Selim, H .M. (20 05). Critical success $\mathrm{f}$ actors for e- learning acceptance: Conf irmatory factor models. Co mputers and Education. Available at http://mail.phy.bg.ac.yu/ marijam/ milos/science7.pdf. 


\section{A Hybrid Course for Probability and Statistics for Engineers: A ReAdiness Study at Shahid Beheshti UNIVERSITY}

[48] Sun, P. C., T sai,R.J., Finger,G., Chen, Y.Y. and Yeh. D.(2007). What drives a successful e-learning? An empirical investigation of the critical factors influencing learner satisfaction. Computer and education, 50(4), 1183-12 02. doi:10.1016/j.compedu. 2006.11 .007

[49] Summers, M. (1990). Starting teacher training-ne w PGC E students and courses. British Education a Res earch Journal. 16, 79-87. doi:10.1080/0141192900160107

[50] Straka,G.A., Kliemann,M., and Stokl,M. (1994). Self organized job. Related lear ning: an em pirical study. International selfdirected learning symposia: Oklahoma Research center for continuing professional and higher education, University of Oklahoma. $149-160$

[51] SORT website, St udent online Readiness Tool website . Available at: http://alt.usg.edu/sort/html/tool.html.

[52] Summers, M. and Easdown, G. (1996). Information technology in initial teacher training: Prec onceptions of history and geography interns, with reflections of mentors and tutors. Journal of Information Technology for Teacher Education, 5, 155-172.

[53] So, T. and Swatman, P.M.C., (2007). E-learning Readiness in the Classroom: a study of Hong Kong primary and secondar y teachers. University of South A ustralia. Availa ble at: http://www.collecter.org/archives/2006-june/22.pdf.

[54] Thurmond, V. A., W ambach, K., and Connors, H. R. (2002). Evaluation of student satisfaction: determining the i mpact of a Web-based environment by controlling for student characteristics. T he A merican Jour nal of Distance E ducation, 16( 3), 169-189. doi:10.1207/S15389286AJDE1603 4
[55] Van Braak, J. (2001). Factors influencing the u se of computer mediated co mmunication by teachers in secondary schools. Computers and Education, 36, 41 - 57. doi:10.1016/S0360$\underline{1315(00) 00051-8}$

[56] Wang, A. Y., and Newlin, M. H. (2002). Predictors of W ebstudent performance: the role of self-efficacy and reasons for taking an on- line class. Co mputers in Hum an Behavior, 18, 151-163. doi:10.1016/S0747-5632(01)00042-5

[57] Watkins, R., Leigh, D. Triner, D. (2004). Assessing Readiness for E-learning. Performance Improvement Quality. 17(4) , 6679 .

[58] Woodrow, J. (1991). Locus of control and computer attitudes as determinants of $t$ he co mputer lite racy of student teachers. Computers and Education, 16, 237 -245. doi:10.1016/03601315(91)90058-Y

[59] Zaharia, P. (2007). Heur istic evaluation in an e-learning context: selecting the appropriate test and reporting usability problems. P roceedings of the 2nd International Conf erence on eLearning. Academic Conferences Limited. 527—534.

\section{AUTHORS}

Amir Teimour Payandeh Najafabadi is with Shahid Beheshti University, Tehran, Iran.

Maryam Omidi Najafabadi is with Islamic Azad University, Tehran, Iran.

Manuscript received January $31^{\text {st }}, 2010$. Published as resubmitted by the authors August $4^{\text {th }}, 2010$.

\section{APPENDIX A. QUESTIONNAIRE ITEMS AND SOURCES}

\begin{tabular}{|c|c|c|}
\hline $\begin{array}{l}\text { Independent vari- } \\
\text { ables }\end{array}$ & Items & Sources \\
\hline $\begin{array}{c}\text { Skills of users } \\
\text { Email skills }\end{array}$ & $\begin{array}{l}\text { How confident do you feel about: } \\
\text { 1. Logging in and out of your account? } \\
\text { 2. Sending and receiving mail? } \\
\text { 3. Attaching and downloading files? } \\
\text { (Likert's scale } 1 \text {, strongly disagree; } 5 \text {, strongly agree) }\end{array}$ & $\begin{array}{l}\text { Nakhoda et al (2006), } \\
\text { SORT website }\end{array}$ \\
\hline Hard ware ability & $\begin{array}{l}\text { How confident do you feel about: } \\
\text { 1. Using a keyboard and mouse? } \\
\text { 2. Basic troubleshooting skills, such as rebooting the computer } \\
\text { in case of a crash and resolving printer errors? } \\
\text { 3. Changing printer ink cartridges? } \\
\text { (Likert's scale } 1 \text {, strongly disagree; 5, strongly agree) }\end{array}$ & $\begin{array}{l}\text { Nakhoda et al (2006), } \\
\text { SORT website }\end{array}$ \\
\hline Soft ware ability & $\begin{array}{l}\text { How confident do you feel about: } \\
\text { 1. Working with fi les, such as creating, saving, a nd printing } \\
\text { documents? } \\
\text { 2. Installing software? } \\
\text { (Likert's scale } 1 \text {, strongly disagree; } 5 \text {, strongly agree) }\end{array}$ & $\begin{array}{l}\text { Nakhoda et al (2006), } \\
\text { SORT website }\end{array}$ \\
\hline Internet ability & $\begin{array}{l}\text { How confident do you feel about: } \\
\text { 1. Logging on to your Internet ser vice provider and navigat- } \\
\text { ing to different Web addresses? } \\
\text { 2. The advanced Internet skills, such as using a search engine, } \\
\text { identifying and downloading appropriate files, or updating } \\
\text { software via Internet? } \\
\text { (Likert's scale 1, strongly disagree; 5, strongly agree) }\end{array}$ & $\begin{array}{l}\text { Nakhoda et al (2006); } \\
\text { Joo et al (2000) } \\
\text { SORT website }\end{array}$ \\
\hline Online Audio/Video & $\begin{array}{l}\text { I think that I would be able to: } \\
\text { 1. Relate the content of short } \mathrm{v} \text { ideo clips }(1-3 \text { minutes ty pi- } \\
\text { cally) to the information I have read online or in books. } \\
\text { 2. Take notes while watching a video on the computer. } \\
\text { 3. Understand cour se related info rmation when it's pres ented } \\
\text { in video formats. }\end{array}$ & Watkins et al (2004) \\
\hline
\end{tabular}




\begin{tabular}{|c|c|c|}
\hline $\begin{array}{l}\text { Self-directed learn- } \\
\text { ing }\end{array}$ & 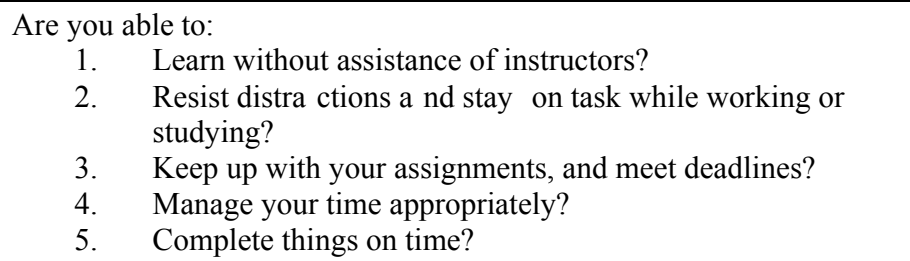 & $\begin{array}{l}\text { Guglielmino an d Gug- } \\
\text { lilmino (2002) Kim } \\
\text { (2005); Graeve (1987); } \\
\text { Straka et al (1994) }\end{array}$ \\
\hline $\begin{array}{l}\text { Learner attitude } \\
\text { toward e-learning }\end{array}$ & $\begin{array}{l}\text { I believe that e-learning : } \\
\begin{aligned} 1 . & \text { is very difficult }(\mathrm{R}) \\
2 . & \text { is very complicated }(\mathrm{R}) \\
3 . & \text { requires technical ability }(\mathrm{R}) \\
4 . & \text { let me feel psychological stress very greatly }(\mathrm{R}) \\
5 . & \text { can be done only if one knows a programming language } \\
& \text { such as Basic }(\mathrm{R}) \\
6 . & \text { is only advisable for people with a lot of patience }(\mathrm{R}) \\
7 . & \text { makes a person more productive at his/her job } \\
8 . & \text { is for young people only }(\mathrm{R})\end{aligned} \\
\text { (Likert's scale } 1 \text {, strongly disagree; } 5, \text { strongly agree) }\end{array}$ & $\begin{array}{l}\text { Gattiker and } \\
\text { (1992) }\end{array}$ \\
\hline $\begin{array}{l}\text { Learner computer } \\
\text { anxiety }\end{array}$ & $\begin{array}{l}\text { I think: } \\
\text { 1. Working with a computer would make me very nervous } \\
\text { I get a sinking feeling when I think of trying to use a com- } \\
\text { puter } \\
\text { 3. Computers make me feel uncomfortable } \\
\text { 4. Computers make me feel uneasy and confused } \\
\text { (Likert's scale 1, strongly disagree; 5, strongly agree) }\end{array}$ & $\begin{array}{l}\text { Barbeite and } \\
\text { Weiss (2004) }\end{array}$ \\
\hline $\begin{array}{l}\text { Equipments } \\
\text { Hard ware }\end{array}$ & $\begin{array}{l}\text { Do you have: } \\
\text { 1. A consistent and convenient access to a computer? } \\
\text { 2. A sound phones or speakers and microphone? } \\
\text { 3. A working printer? } \\
\text { 4. A CD-ROM drive? } \\
\text { 5. A flash-stick memory? } \\
\text { 6. A laptop? }\end{array}$ & $\begin{array}{l}\text { SORT website } \\
\text { Watkins et al (2004) }\end{array}$ \\
\hline Software & $\begin{array}{l}\text { Do you have: } \\
\text { 1. A Web browser, such as safari , fire-fox, Intern et explorer, } \\
\text { on your computer? } \\
\text { 2. A virus protection software on your computer? } \\
\text { 3. The Microsoft package on your computer? }\end{array}$ & $\begin{array}{l}\text { SORT website } \\
\text { Watkins et al (2004) }\end{array}$ \\
\hline Internet & $\begin{array}{l}\text { Do you have: } \\
\text { 1. A reliable Internet connection? } \\
\text { 2. A high-speed Internet connection? }\end{array}$ & $\begin{array}{l}\text { SORT website } \\
\text { Watkins et al (2004) }\end{array}$ \\
\hline Dependent variables & Items & Sources \\
\hline readiness & $\begin{array}{l}\text { 1. I have enough IT skills to use e-learning technologies. } \\
\text { 2. My par ents are read y to suppo rt the use of e-learning at } \\
\text { home. } \\
\text { 3. I think I am ready for e-learning } \\
\text { 7. I think I am rea dy to take m y quizzes, assignments, extra } \\
\text { examples from the web. } \\
\text { 8. I think I am ready to communicate with instructors and stu- } \\
\text { dents via the web. } \\
\text { 4. I think it is the right tim e to promote e-learning in universi- } \\
\text { ties } \\
\text { 5. Taking this c lass in this m anner allow m e to a rrange my } \\
\text { work for the class more effectively. } \\
\text { 6. The advantages of taking this class in this mann er outweigh } \\
\text { any disadvantages } \\
\text { 7. Taking this class in this manner allow me to see course lec- } \\
\text { tures which I was absent in that lessons } \\
\text { (Likert's scale } 1 \text {, strongly disagree; } 5 \text {, strongly agree) }\end{array}$ & $\begin{array}{l}\text { Arbaugh(2000) Thur- } \\
\text { mond et al (2002) } \\
\text { So and Swatman (2007) } \\
\text { And self-development }\end{array}$ \\
\hline
\end{tabular}

